\title{
MATERNAL HEPATITIS C (HCV) INFECTION AND ANTI-D IMMUNOGLOBULIN THERAPY: STUDY TESTING ANTIBODIES, RNA AND GENOTYPE OF HCV IN BAGHDAD
}

\author{
Waqar Al-Kubaisy'), Suzanna Daud ${ }^{2)}$, Mustafa Waseem Al-Kubaisy3), \\ Omar Waseem AL-Kubaisy4), NikNairan Abdullah' ${ }^{1)}$ \\ 1)Population Health and Preventive Medicine, Faculty of Medicine, \\ Universiti Teknologi MARA, Malaysia. \\ 2)Obstetrics and Gynaecology Discipline, Faculty of Medicine, \\ Universiti Teknologi MARA, Malaysia \\ 3)Faculty of Dentistry, Dajlah Universiti, Baghdad, Iraq \\ 4)Faculty of Pharmacy, Al Essra'a Universiti, Amman, Jordan
}

\begin{abstract}
Background: Hepatitis $\mathrm{C}$ virus (HCV) infection is a serious health problem worldwide. About 130 - 200 million people, and 1- 8\% of all pregnant women were infected. It is a major contributor to end-stage liver disease. Women with viral hepatitis may be at an increased risk of pregnancy complications. Several obstetrics intervention act as risk factors which are specific to women pertaining the HCV infection; anti-D immunoglobulin (Ig) therapy may be one of them. The objectives of this sudy were to estimate the prevalence of HCV antibodies (anti$\mathrm{HCV}$ ), RNA as well as HCV genotype among women with a history of anti-D Ig therapy.

Subjects and Method: A cross sectional study was carried out involving 154 Rhesus negative (Rh-ve) blood group pregnant women regardless of the anti-D Ig therapy. Anti-HCV was tested using third generation enzyme immunoassay (EIA-3) and immunoblot assay (Lia Tek-111), subsequently. In addition, 89 serum samples were subjected to molecular analysis using RT-PCR and DNA enzyme immunoassay (DEIA) method for HCV-RNA and genotypes.

Results: Anti-HCV and HCV-RNA seroprevalence were higher (17.1\%, 35.5\%) among recipients of anti-D Ig than their counter group $(6.4 \%, 13.16 \%$, respectively), and it was stastically significant $(\mathrm{p}=0.038, \mathrm{p}=0.010$, respectively). Significant direct positive dose response correlation $(r=0.78, p=0.005)$ had been seen between number of anti-D Ig and anti-HCV seropositive rate. Anti-D Ig therapy act as a risk factor (OR=3.01, 95\% CI: 1.01 to 8.9$)$ especially from the third dose onward. Women with anti-D Ig therapy were at higher risk (3.6 times more) of positive HCV-RNA $(\mathrm{OR}=3.6,95 \% \mathrm{CI}=1.19$ to 10.837$)$. HCV-1b showed higher prevalent (52.9\%) among the recipients of anti-D Ig therapy while genotype $\mathrm{HCV}-3 \mathrm{a}(6.6 \%)$ was the lowest.

Conclusion: This study showed that Anti-D immunoglobulin therapy acts as a risk factor for $\mathrm{HCV}$ infection. Screening for $\mathrm{HCV}$ is recommended for all recipients of anti-D Ig. Not only HCV antibodies but also HCV-RNA detection is recommended for the diagnosis of $\mathrm{HCV}$ infection.
\end{abstract}

Keywords: maternal health, hepatitis $\mathrm{C}$ virus (HCV), anti-D immunoglobulin, HCV genotypes, risk factor

Correspondence: Prof. Dr. Waqar Al-Kubais, Population Health and Preventive Medicine (PHPM). Faculty of Medicine, Universiti Teknologi MARA (UiTM), Sungai Buloh Campus, Jalan Hospital, 47000, Sungai Buloh Selangor, Malaysia. Email: waqar_abd@yahoo.co.uk. Mobile: +60172731647. 